\title{
Repliek op die Yonge-artikel
}

\author{
IRMA ELOFF \\ Departement Opvoedkundige Sielkunde \\ Universiteit van Pretoria \\ Pretoria \\ Suid-Afrika \\ E-pos: irma.eloff@up.ac.za
}

\section{Die tydsgees, diversiteit van perspektief en die wetenskap: Repliek op George Yonge}

So nou en dan kruis 'n artikel of 'n boek of 'n hoofstuk of selfs 'n tesis 'n mens se pad wat jou herinner aan die rede waarom jy in die akademie werk, iets wat jou herinner aan die wesensaard van die akademie, die hart van die wetenskaplike wêreld. Die artikel van George Yonge getiteld "'n Onwaarskynlike onderneming: 'n Ondersoek na die kritiek rakende fundamentele pedagogiek" (Yonge, 2021) was so 'n artikel.

Alhoewel die inhoud van die artikel as geheel 'n interessante benadering tot die geskiedenis van kurrikula in onderwysersopleiding aan 'n Suid-Afrikaanse universiteit is, is dit veral die implisiete aspekte van die onderwerp wat Yonge aanroer wat stof tot nadenke bied:

- Om bewerings te staaf

- Om bo die tydsgees uit te styg

- Om diverse sienings aktief te soek

- Om altyd dieper te delf

- Om jouself te bevraagteken

In hierdie artikel reflekteer Yonge oor sy eie groei terwyl hy die fundamentele pedagogiek verken het, veral soos hy dit aangetref het in die werk van navorsers in Pretoria in die sewentiger- en tagtigerjare. Hy skets spesifiek sy soeke na teoreties begronde antwoorde terwyl hy opvoedkundige sielkunde aan studente in die VSA gedoseer het. Hy verduidelik die trajek van sy besoek aan Pretoria in 1980 en die gevolglike aanpassing van sy kurrikulum ná sy terugkeer na die VSA. Veral die invloed van Langeveld en die kategoriese strukturering van die opvoedingsfenomeen, soos in die fundamentele pedagogiek voorgestel, kom onder skoot. Tekortkominge word uitgewys. Raakpunte word uitgelig. Meer nog, die ontwikkeling van die vakgebied binne die sosio-politieke omgewing van die tyd word geskets. Sy eie posisionaliteit as 'n Demokraat (soos gedefinieer in die huidige VSA-landskap) en nie-Christen word verklaar. Hy bevraagteken dan die bewerings oor die assosiasie van die fundamentele pedagogiek met die apartheidsonderwys van die tyd. Yonge se bevraagtekening van hierdie proses word gedoen aan die hand van 'n tydlynanalise wat die ontwikkeling van die fundamentele pedagogiek delinieer en teenstrydighede uitwys. Dit word ook gedoen deur op wanvertolkings te wys, veral beperkte insig in die gebruik van tussen-hakies-plasing (bracketing) in die fenomenologie, en selektiewe ignorering van sekere kernkategorieë in die fundamentele pedagogiek.

Hierdie artikel van Yonge het my spreekwoordelik laat regop sit. As 'n student in die tagtiger- en vroeë negentigerjare moes ek self die basisstrukture van die fundamentele pedagogiek vir menige toets en eksamen in verskeie modules onder die knie kry. Die handboeke 
was dik. Teoretiese konsepte soos "Dasein" ('daar wees, teenwoordig wees'), "Mitsein" ('saamwees') en “Aha-Erlebnis” ('die oomblik van insig') het weerklank gevind in my praktiese onderwysleerervarings as 'n jong student. Terselfdertyd was dit ook 'n tyd van kritiese, sistemiese selfondersoek in die land, herkurrikulering op alle vlakke en radikale onderwysbeleidsverskuiwings. Die tydsgees was opwindend en die geleenthede vir grootskaalse veranderinge in die onderwysstelsel was haas onbeperk. Die handboeke op my boekrak en die studienotas in my lêers het al hoe meer geword. Paulo Freire, John Dewey, Jerome Bruner, Margaret Bancroft, Maria Montessori, Reuven Feuerstein, Lev Vygotsky.

Dit was egter nie net die herinneringe aan my eie studie wat my laat wonder het nadat ek die Yonge-artikel gelees het nie. Ek het ook gewonder oor al die kere dat bewerings gemaak is wat bloot net aanvaar is sonder om hulle empiries te ondersoek: "Waarop baseer jy jou stelling?" "Waar hoor jy dit?" "Wie het dit gesê?" "Wat is jou bronne?" "Klop dit wat hier gesê word?" - dit is die basiese vrae wat in enige oriënterende navorsingsmetodologiekursus gedek word.

Yonge bevraagteken 'n spesifieke assosiasie tussen die fundamentele pedagogiek en apartheidsonderwys, dekades nadat dit gevorm is. Hy doen dit deur te wys op die gebrek aan empiriese bewyse vir sekere aannames, en deur teenstrydighede uit te lig. Hy huiwer nie om sy standpunt te stel nie, al is dit onafhanklik van die tydsgees waarin dit gestel word. Dit is outonoom en nie beïnvloed deur die (oor)heersende standpunte oor die kurrikulum vir onderwysersopleiding in 'n nuwe demokrasie nie. Dit bepleit die behoud van wetenskaplike ondersoek, en die versigtige omgang met die simbiotiese dinamiek tussen die dominante sienswyses van die tyd, teoretiese diversiteit en kurrikula.

Diversiteit van perspektiewe is veronderstel om aan die kern van die akademie te lê. Uiteenlopende sienings versterk die wetenskap, verdiep die kwaliteit van dialoog en bied boonop dikwels verligting en verheldering - veral as die denkfoute in jou eie argumentasielyn uitgewys word. Dit bring verryking. Diversiteit van perspektiewe, ten spyte van die dominante ideologieë van die tyd, skep die moontlikheid vir ryker, meer genuanseerde sienswyses. Dit skep ook die moontlikheid dat sienings kan verbreed, kan verskerp en hopelik ook kan verskuif. Implisiet in Yonge se artikel is die veronderstelling dat ons as wetenskaplikes, selfs terwyl ons dit wat totaal verwerplik is (bedoelende die apartheidsonderwys) ondersoek, steeds 'n verantwoordelikheid het om diversiteit van perspektief te beskerm.

Die impuls om dieper as die oppervlak te delf, is ook implisiet in Yonge se artikel aanwesig. Die vraag wat egter by die eerste lees van die artikel reeds by 'n mens opkom, is: Waarom nou? Dit behels immers gebeure en beskouinge van dertig, veertig, selfs vyftig jaar gelede. Die meeste hedendaagse studente ken nie eers die term "fundamentele pedagogiek" nie, en die dosente of oudstudente wat dit wel herken, se boeke is lank reeds weggepak of staan eenkant op die boekrak. En tog is dit nog 'n deel van die wetenskap en die akademiese wêreld wat destyds vir my as 'n jong student en later dosent 'n bekoring ingehou het - die dieper delf. 'n Mens kan mos altyd dieper delf, altyd reflekteer oor die geskiedenis, en altyd vroeëre sienswyses herbesoek en herevalueer. Ons het eintlik 'n plig om dit te doen, sodat ons beter kan vaar. Ons kan steeds soveel by Heidegger en Husserl leer, dikwels meer as by die groot geeste van ons eie tyd. 'n Mens kan en moet ook by jou medemens leer, soms sodat jy kan nadink oor dit wat uitgebou kan word, en soms om te bepaal wat nie meer onderskryf moet word nie, hoe om dit nie te doen nie - soos in die geval van die fundamentele pedagogiek. Die siklus is egter nog nie beëindig nie, want selfs dié onderdeel van die opvoedkunde kan ook weer in oënskou geneem word. 
Dit blyk dus dat die lees van die Yonge-artikel verskeie gewaarwordinge kan aktiveer: Kritiek rakende 'n hele vakgebied wat sonder meer so aanvaar is en nie betwis is nie? Wanvertolkings van kernkonsepte wat nie bevraagteken is nie? Was dit die tydsgees? Watter omstandighede het dit moontlik gemaak? Byna onwillekeurig kom die vraag ook by mens op: Is wat op die oomblik besig is om te gebeur, in sommige opsigte dalk soortgelyk aan dit wat dekades gelede met die fundamentele pedagogiek gebeur het? Watter aspekte van die opvoedkunde en onderwys word in die huidige tydsgees genegeer?

Yonge lewer 'n pleidooi vir omsigtigheid, en voer aan dat dit kortsigtig is om die teoretiese insigte van 'n hele segment van 'n vakgebied verlore te laat gaan. Hy wys op die problematiek van 'n ongemotiveerde assosiasie, selfs terwyl hy ook krities staan teenoor bepaalde teoretiese aannames binne die vakgebied van die fundamentele pedagogiek. Hy kontekstualiseer sy verkenning van die vakgebied van die fundamentele pedagogiek aan die hand van W.Luijpen se Existential phenomenology en ook Merleau-Ponty se Phenomenology of perception, en hy dui die aanknopingspunte met gestaltsielkunde aan.

"In 1974," sê Yonge, "het ek 'n resensie van BF Nel se Fundamental Orientation in Psychological Pedagogics (wat in April 1968 in Afrikaans as Fundamentele oriëntering in die psigologiese pedagogiek uitgegee is en in September 1973 in Engels verskyn het) in die Journal of Phenomenological Psychology gelees en die boek uit Suid-Afrika bestel." Dit was sy "eerste kennismaking met die fenomenologiese studie van onderrig/opvoeding wat deur die Fakulteit Opvoedkunde aan die Universiteit van Pretoria bestudeer is". Dit het uitgeloop op 'n diepgaande verkenning van die werk van Landman, Nel, Pretorius, Sonnekus, Van der Stoep en Louw, Van Niekerk, en verskeie ander in Pretoria (Landman et al., 1975; Nel, 1973; Pretorius, 1979; Sonnekus, 1968; Van der Stoep et al., 1973; Van der Stoep \& Louw, 1979; Van Niekerk, 1982).

Yonge tref in sy artikel pertinent 'n onderskeid tussen wetenskaplikheid en nawetenskaplikheid. Hy suggereer die belang van die tydsgees, en hy erken die belangrikheid van die sosio-politieke konteks waarbinne wetenskaplikheid bedryf word. Hy wys spesifiek ook op die verskille tussen dit wat wetenskaplik gebesig word, en dit wat dan nawetenskaplik geïnterpreteer word. En miskien is dit juis hier waar die belangrikste bydrae van die Yongeartikel na vore tree: om die breë grys gebied tussen wetenskap en die populêre sienswyses van die tyd te belig; om aan te dui dat, hoewel verbandhoudend, wetenskap en "nawetenskap" soms verskil en nie verwar moet word nie.

In hierdie verband skryf Thomas S Kuhn in The structure of scientific revolutions dat "waarhede" dikwels meer geredelik uit wetenskaplike denkfoute as uit verwarring voortspruit, en dat "even when the apparatus exists, novelty ordinarily emerges only for the man who, knowing with precision what he should expect, is able to recognize that something has gone wrong" (Kuhn, 2012:65).

\section{BIBLIOGRAFIE}

Kuhn, TS. 2012. The structure of scientific revolutions. (3 ed.). Chicago, IL: University of Chicago Press. Landman, WA, Roos, SG \& Liebenberg, CR. 1975. Opvoedkunde en opvoedingsleer vir beginners. Stellenbosch: Universiteitsuitgewers en Boekhandelaars.

Nel, BF. 1973. Fundamental orientation in psychological pedagogics. Stellenbosch: University Publishers \& Booksellers.

Pretorius, JWM. 1979. Opvoeding, samelewing, jeug: 'n Sosiopedagogiekleerboek/Education, society, youth: A sociopedagogic textbook. Pretoria: JL van Schaik.

Sonnekus, MCH. 1968. The learning child. Johannesburg: McGraw-Hill. 
Van der Stoep, F (red.), Van Dyk, CJ, Louw, WJ \& Swart, A. 1973. Die lesstruktuur. Johannesburg: McGraw-Hill.

Van der Stoep, F \& Louw, WJ. 1979. Inleiding tot die didaktiese pedagogiek. Pretoria: Academica.

Van Niekerk, PA. 1982. The teacher and the child in educational distress. Stellenbosch: University Publishers \& Booksellers.

Yonge, G. 2021. 'n Onwaarskynlike onderneming: 'n Ondersoek na die kritiek rakende fundamentele pedagogiek. Tydskrif vir Geesteswetenskappe, 61(4-2):1327-1345. 